胸壁血腫を契機に見いだされた肋骨 desmoplastic fibroma の 1 例

国 府 充 央 黑 川 $\begin{aligned} & \text { 箕面市立病院外科 } \\ & \text { 大阪医科大学病理 } \\ & \text { 森 浩 志 }\end{aligned}$

Desmoid 腫瘍は，通常，筋・健膜構造より発生する線維性腫場であるが，骨組織に発 生するものは desmoplastic fibroma として区別されている. 今回，胸壁血尰を契機に見 いだされた肋骨 desmoplastic fibroma を経験したので報告する，症例は，42歳女性，外 傷歴は特になし. 右胸痛にて近医受診.X線写真, CT 検查にて右胸壁血尰を指摘され当 科紹介となった．来院時，右第 2 助骨部に宿凹が認められた。ドレナージ術を施行し， 血腫はほぼ消失したが，X線写真，CT 検查にて右第 2 肋骨に腫瘍像が認められた。同部 の open biopsy を行ったところ, desmoplastic fibroma と診断された。 そこで，第 1 助 骨下縁，第 2 助骨を含めて重場を切除し，胸壁欠損部は，Marlex mesh で再建した。切 除尰場は，非常に硬く，一部に烡胞を認め，組織学的に助骨原発の desmoplastic fibroma であった．現在，術後32カ月で再発は認められていないが，今後，敩重な释過観察を行 う予定である。

象引用語：Desmoplastic fibroma，助骨 desmoplastic fibroma，線維性骨重瘍

\section{藉 豆}

1958年 Jaffe $\mathrm{e}^{1)}$ は, 線維性骨腫瘍のうち軟部の desmoid 腫漡に類似した組織像を示するのを desmoplastic fibroma と報告している. 以来, desmoplastic fibromaは,まれな腫瘍とされている.一般的に長管骨 が好発部位であり，胁骨に発生するるのは，部位的に きわめてまれである。

今回，胸壁血腫を契機に見いたされるといら特異的 な経過をたどった肋骨原発の desmoplastic fibroma の 1 例を経匰したので若干の文献的考察を加えて報告 する。

$$
\text { 症例 }
$$

患者：42歳，女性.

主訴：右胸痛.

既往歴：2 児出産，外偒の既往なし。

家族歴：特記すべきことなし。

現病歴：平成 1 年 9 月初めより心窝部から右胸部に かけて疼痛が出現した。痛みが持続するため近医を受 診し，胸部 X 線写真, CT 検查等で右胸壁庫瘤を指摘

1992年 9 月 7 日受付 1993年 4 月16日採用
され，当院を紹介され9月22日当科を受診した. 同日， 胸壁血腫疑いにて超音波がイド下に穿刺を行ったとこ ろ，濃茶色のやや粘調な液体を吸引した，細胞診は陰 性であった.9月28日,ドレナージ術目的に入院となっ た.

入院時現症：右第 2 助骨部に軽度陷凹が認められた が，王痛，発赤は認められなかった。また，腹部，四 肢に特に異常は認められなかった。

入院時検查成績：特に異常は認められなかった。

胸部 X 線写㚓検查：右中肺野から下肺野にかけて 境界明瞭な庫瘤陰影が認められた（図 1).

CT 検查：右肺中部から下部にかけて胸壁から胸腔 に突出する属瘤が認められ，腫瘤内部には，鏡面像が 認められた。以上より，右胸壁血腫と診断し，9月29 日ドレナージ術を施行した。

入院後経過：ドレナージ術後，血尰は縮小㑯向を示 し，10月9日カテーテルを技去したが，胸部 X 線写真 挨査にて，右第 2 肋骨に腫湯像が認められた（図 2 ）。 CT 検查です，右第 2 助骨の骨破壊像がみられ，胸壁よ り胸腔へ突出する腫瘤像が認められた（図3）。なお， 昭和63年11月の健診時の胸部 X 線写真でも同様の所 


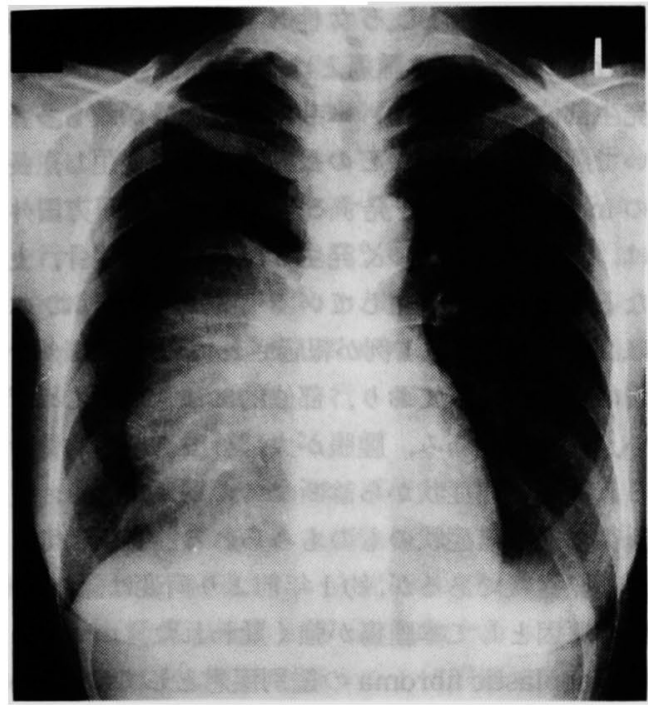

图 1 初診時胸部 X 緗写真

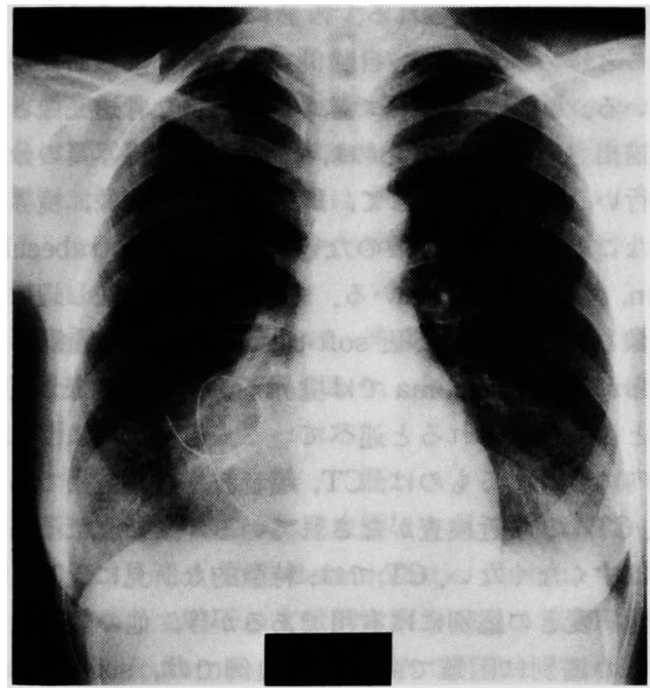

図 2 ドレナーシ徒後の胸部 X 線写真: 肺野の尰痹 陰影の消失後に，右第 2 肋骨に畽瘍像が笁められた。

見が認められた(図4)，10月11日，一旦，退院となり，

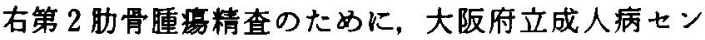
ター整形外科を受診した。骨シンチにて特に異常なく， 11月21日, open biopsy $に て$, desmoplastic fibroma と診断され，手術目的にて，12月20日再入院，12月21 日手術を施行した。

手術所見：前胸部にて開胸を行ったところ,腫瘍は, 第 2 助骨の肋軟骨移行部より発生し, 啋卵大であった。 第 2 肋骨を切断し，肋間筋を充分に含めて，第 1 助骨

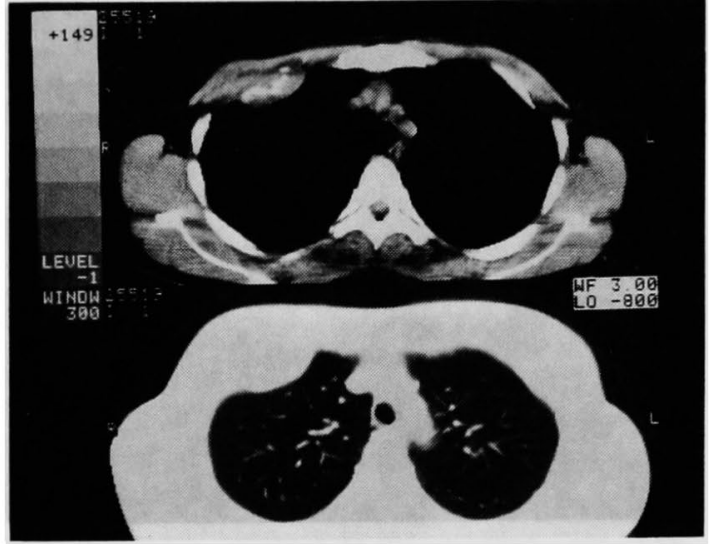

図 3 ドレナージ術啳の CT 像

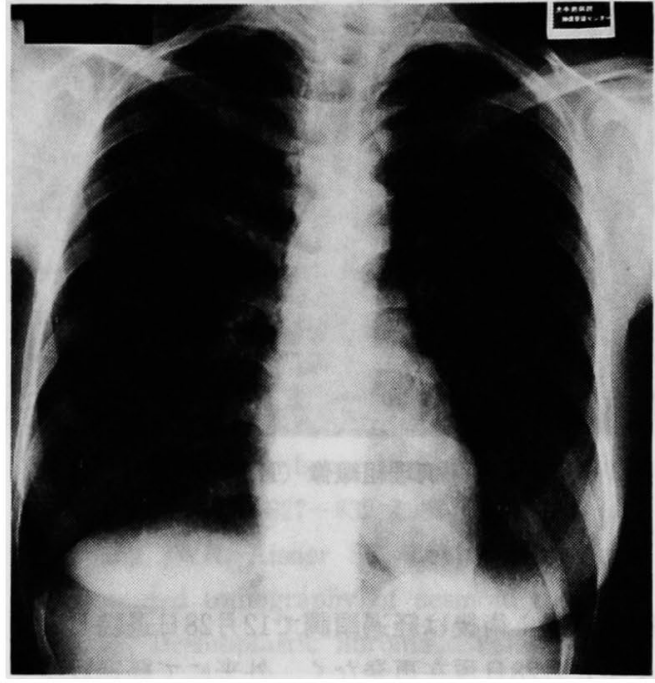

図 4 検診時の胸部 X 線写真：右第 2 肋骨に腫煌像 が認められた。

下縁の一部と共に, 畽瘍を摘出した。胸壁欠損部には, 二重にした Marlex meshを用い，再建を行った。

切除標本：畽湯の大きさは， $4.2 \times 3.5 \times 2.2 \mathrm{~cm}$ で, 白色，充実性で，非常に硬く，境界は不明瞭で，一部 に多房性震胞を認め，内容は，漿液性であった（図 5 ).

組織学的所見：膠原線維が波打つよ5にみられ，そ の間に比較的長い核をむった紡錘形の線維芽細胞の増 殖がみられた，核の異型にそしく核分裂像がほとんど 見られなかった。畽瘍は，明瞭な被膜を有しておらず， 破壊された骨梁と軟骨の残存が一部に認められ，助間 筋への浸潤が認められた（図 6 )。

以上より, 肋骨原発の desmoplastic fibroma と診断 


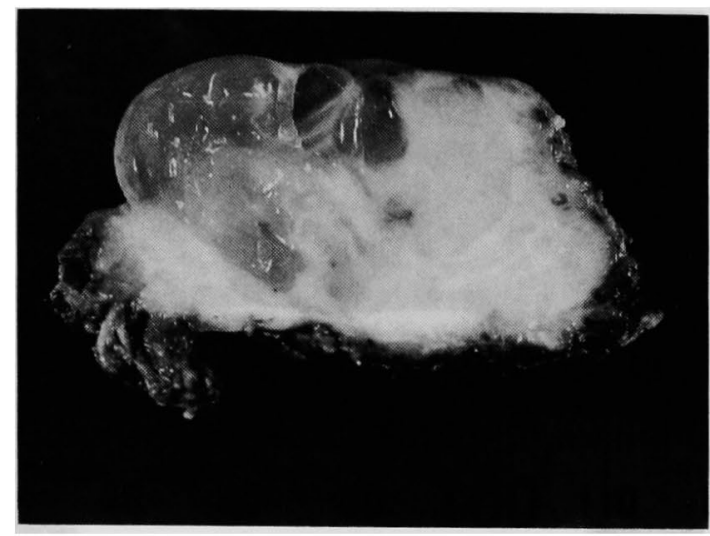

图 5 搭出儤本

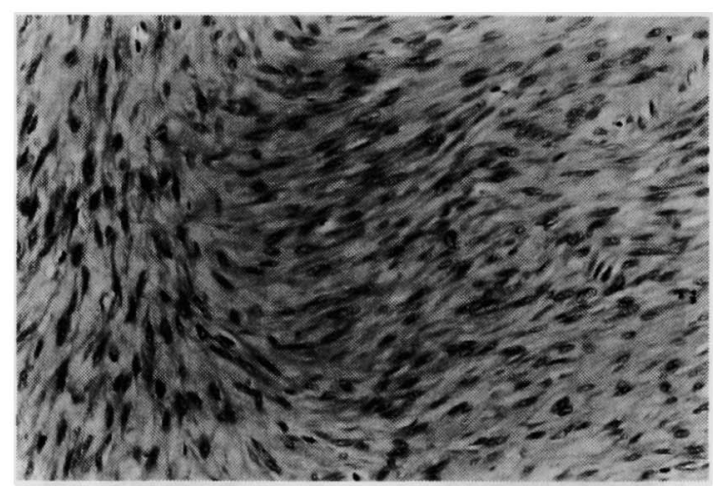

图 6 病理組彎像 (H.E. $\times 400)$

した。

術後経過：術後は経過順調で12月28日退院した。平 成 4 年 8 月 28 日現在再発なく，外来にて経過観察中で ある。

\section{考 察}

軟部腫場である desmoid畽煌は, 1832 年 Macfarlene ${ }^{2}$ が, 初めて 2 例の腹壁腫瑒を報告し, 1838

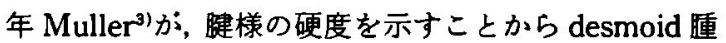
場と名付けたのに始まる。一方，1958年 Jaffe ${ }^{1 /}$ は，線 維性骨腫場の5ち desmoid 腫湯に類似した組織像を 示寸腫瘍を desmoplastic fibroma として報告し, 以来 desmoplastic fibromaはまれな腫瘍とされている. Dahlin 54は, Mayo Clinic の原発性骨腫灌8，542例中 9 例 (0.1\%) であったと報告しており，全国骨睡煬登 録)では, 1972 1987年の原発性骨腫瑒31，360例中63 例 $(0.2 \%)$ であった，年龄では，広い範囲にわたってて いるが若年者に多く発生し30葴以下が大部分をしめて いる，性別では，性差はないかや男性に多く発生す
る傾向にありむしろ女性に多く発生する extraabdominal desmoid 腫瘍とは, 対称的である ${ }^{6}$.

発生部位に関しては，本邦では大㙟骨が最も多く， 次いで脛骨，上腕骨などの長管骨に多く発生し，長管 骨の metaphysis に好発する傾向にある。一方国外例 では，下晾骨に最も多く発生し，次いで大眼骨，上腕 骨などの長管骨に発生している7. 助骨発生例は, 本邦 では 2 例登録され，1例が報告されておりタ，国外でる 2 例の及報告されており，部位的にはきわめてめずら しい，症状は，痛み，聥脹が大部分であり病的骨折も みられるが初発症状から診断までの期間が長く, 生長 は緩徐であり無症状のものるみられる. 自験例でも胸 痛が初発症状であるが, 䄪 1 年前より病变は認められ， 血腫の原因として本腫湯が強く疑われた。

Desmoplastic fibroma の鑑別疾患としては, fibrous dysplasia, aneurysmal bone cyst, chondromyxoid fibroma, non-ossifying fibroma, low-grade fibrosarcoma などがあげられる，術前に生検なしで診断のつ くことはめずらしく，自験例です生検にて診断がつい ている。単純 X 線写真では, 境界明瞭な骨透亮像とし

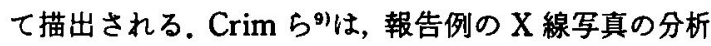
を行い，その特徵として，地図状の骨破壊像，境界明 瞭なこと，辺縁硬化像のないこと，pseudotrabeculation，骨膨隆をあげている。また，末梢に存在し辺縁硬 化像などがみられると soft-tissue desmoid畽煬が考 えられ，fibrosarcoma では境界不明瞕な虫喰様骨破塤 像として描出されると述べている，自験例のよ5に胸 腔内に発育するるのは，CT，超音波険查が有用であっ た.CTは，最近検査がなされているがまだまだその報 告はすくなくない.CT では，特徽的な所見に乏しく㻃 胞性病変との鑑別には有用であるが10)，他の線維性病 变との鑑別は困難である. 自験例では, soft tissue density として描出されて找り同様の報告すなされて いる(1). CT では，質的診断よりるむしろ周辺軟部組䋐 への浸潤の程度など, 病変の進展範囲の評価にすぐれ でり，術前にぜひ必要な検査である，自験例では施 行していないが血管造影では, hypovascular な報告例 が多いままた，RIでは，up takeが認められるといら 報告が多いか，自験例では，集皘は認められなかった。

組織学的には，様々な量の翏原線維を伴った紡錘型 の細胞で，やゃ長い核を有し核分裂像は認められない。 鑑別で問題になるのは, low-grade fibrosarcoma であ ク，その鑑別は必ずしも容易ではない，fibrosarcoma は，多形性であり，細胞成分が多く，核はクロマチン 
に富み，核分裂像る認められる，再発による悪性化や 転移は，1 例の及報告されているにすぎず，現在では 悪性化や転移はないと考えられている。

治療に関しては，摄爬および骨移植，切除が行われ ていろか再発率はきわめて高い.Gebhardt ら 爬を行ったるのの再発率は42\%であり，切除を行った ののでは25\%に再発が認められたと報告している。一 方 Inwards ら์(1)，提爬したすのは全例再発が認めら れたが, wide resectionを行ったるのには再発は認め られていないと述へている。

Desmoplastic fibroma は，部位的に切除か困難なも のが多いが, 助骨のような切除可能病変はできるだけ wide resection が望ましいと思われ自検例では，少な

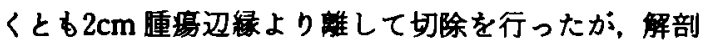
学的にそれ以上の切除を行らことは困難であった。 な お，本垁患では術前に診断をつけておくことはきわめ て重要である。 desmoplastic fibromaは，他の良性線 維性病変より aggressive であり，切除が不十分である と再発をきたしやすい，また low-grade fibrosarcoma では，さらに radicalな手術必要である。 amputation К関しては, desmoplastic fibroma は, 悪性化ゃ 転移をおこさず，その実施はできるだけ避けるべきで ある。また，放射線療法や化学療法は一般には行われ ていない.

Desmoplastic fibroma は，再発をきたしゃすく，10 年以上たっての再発例的あり，今後の注意深い经過 観察が必要であると思われる。

$$
\text { 結 語 }
$$

胸痛を主訴として，胸壁血畽より見いだされた，き わめてめずらしい肋骨 desmoplastic fibroma の 1 例 を経呀したので若干の文献的考察を加えて報告した。 desmoplastic fibroma は，きわめて再発をきたしやす く，広筝囲に切除を行ったが今後の爰重な経過観察が 必要であるとおすわれる.

本詥文の要旨は第32回関西胸部外科学会にて発表した (1991年 6 月富山).
文献

1) Jaffe HL: Tumors and tumorous conditions of the bones and joints, Lea \& Febiger, Philadelphia, 1958, p298-303

2) Macfarlene J : Clinical reports of the surgical practice of the Glaslow Royal Infirmary, D Robertson, Glaslow, 1832, p63-66

3) Muller J: Uber den freinern Ban und die Formen der Krankhaften Geschwulste. Berlin, G Reimer 1838, p60

4) Dahlin DC, Unni KK : Bone tumors, general aspects and data on 8,542 cases, 4 th Ed, Charles C Thomas, Springfield Illinois, 1986, p375-378

5）全国骨腫患者登録一稘表，昭和62年度症例, 国立 がんセンター，東京， 1989

6) Inwards CY, Unni $\mathrm{KK}$, Beabout JW, et al : Desmoplastic fibroma of bone. Cancer $68: 1978$ $-1983,1991$

7) Graudal N: Desmoplastic fibroma of bone. Case report and literature review. Acta Orthop Scand $55: 215-219,1984$

8）高木克公，田村和弘，大平 他：助骨に発生した desmoplastic fibromaの 1 症例. 整形外科 34 : $310-312,1983$

9) Crim JR, Gold RH, Mirra JM, et al: Desmoplastic fibroma of bone : Radiographic analysis. Radiology $172: 827-832,1989$

10) Young JWR, Aisner SC, Levine AM, et al: Computed tomography of desmoid tumors of bone: Desmoplastic fibroma, Skeletal Radiol $17: 333-337,1988$

11）五十崖康美。遠藤 崇, 服部 彰他：腸骨に発生し た desmoplastic fibromaの 1 例. 整災外 29 : $1843-1845,1986$

12) Gebhardt MC, Campbell CJ, Schiller AL, et al : Desmoplastic fibfoma of bone. A report of eight cases and review of the literature. J Bone Joint Surg $67: 732-747,1985$ 


\title{
A CASE OF DESMOPLASTIC FIBROMA OF THE RIB DIAGNOSED BY SHOWING A HEMATOMA OF THE CHEST WALL
}

\author{
Ikuo KOKUFU, Eiji KUROKAWA, Seigoh MIZUMOTO and Masanori KISHIBUCHI \\ Department of Surgery, Minoh City Hospital \\ Hiroshi MORI \\ Department of Pathology, Osaka Medical College
}

Desmoid tumor is a fibrous tumor commonly arising in the muscle and aponeurotic structure. The tumor arising in the bone is discriminated as desmoplastic fibroma, which is a rare bone neoplasm. This paper describes a case of desmoplastic fibroma of the rib which presented with hematoma of the chest wall.

A 42-year-old woman consulted a nearby hospital for right chest pain, and was pointed out having a hematoma of the right chest wall by X.P and CT. There was no previous history. The patient was referred to the hospital. On admission, the concavity of the anterior chest wall was shown. After the drainage, the hematoma was almost diminished. However, chest X-P revealed a tumor shadow at the right 2 nd rib and CT scan visualized the tumor growing into the thorax. Open biopsy revealed the desmoplastic fibroma. The tumor was excised en block, including the 2nd and the lower part of the 1st ribs. The chest wall was reconstructed with Marlex mesh. The tumor was very hard and the cystic lesion was shown. The histopathological diagnosis was desmoplastic fibroma that was made up of wavy fibloblasts and abundant collagenous tissue.

The patient is well and has a disease-free period of 32 months after the operation. Based on a fact that desmoplastic fibroma recurs in a high rate, the patient should not be lacked for further careful and frequent follow-up. 